\title{
Toll-like Receptors are Key Participants in Innate Immune Responses
}

\author{
SERGIO A ARANCIBIA, CAROLL J BELTRÁN, ISABEL M AGUIRRE, PAULINA \\ SILVA, ALEXIS L PERALTA, FRANO MALINARICH and MARCELA A HERMOSO
}

Laboratorio de Inmunidad Innata, Programa Disciplinario de Inmunología, Instituto de Ciencias Biomédicas (ICBM), Facultad de Medicina, Universidad de Chile, Santiago, Chile.

\begin{abstract}
During an infection, one of the principal challenges for the host is to detect the pathogen and activate a rapid defensive response. The Toll-like family of receptors (TLRs), among other pattern recognition receptors (PRR), performs this detection process in vertebrate and invertebrate organisms. These type I transmembrane receptors identify microbial conserved structures or pathogen-associated molecular patterns (PAMPs).

Recognition of microbial components by TLRs initiates signaling transduction pathways that induce gene expression. These gene products regulate innate immune responses and further develop an antigen-specific acquired immunity. TLR signaling pathways are regulated by intracellular adaptor molecules, such as MyD88, TIRAP/Mal, between others that provide specificity of individual TLR- mediated signaling pathways. TLRmediated activation of innate immunity is involved not only in host defense against pathogens but also in immune disorders. The involvement of TLR-mediated pathways in auto-immune and inflammatory diseases is described in this review article.
\end{abstract}

Key terms: Toll-like receptors, Innate Immunity, cytokines, MyD88, NFkB.

\section{INTRODUCTION}

Host defense against invading pathogens is driven by the immune system that can be divided into two branches: innate and acquired immunity. Innate immunity recognizes invading microorganisms as non-self, triggering immune responses to eliminate them. Acquired immune response identifies specific pathogen peptides presented by antigen presenting cells and activates humoral and cellular immune responses.

At the moment, both immune responses have been characterized separately; in the immunology field attention has been mainly confined to acquired immunity. However, the innate immune system in mammals has yet to be fully studied. Although mammalian innate immune cells, represented by macrophages and dendritic cells are known to be activated by microbial components (non-self), such as lipopolysaccharide (LPS) from Gramnegative bacteria, a specific receptor for LPS recognition remained unknown for long time.

In the late '90s, Toll was described to be an essential receptor for Drosophila defense against fungal infection, restricted to an innate immune response (1). One year later, a mammalian homologue of the Toll receptor, Toll-like receptor 4 (TLR4) was shown to induce expression of inflammatory genes (2). In addition, a point mutation in the TLR4 gene, has been

Corresponding Author: Marcela A. Hermoso, Laboratorio de Inmunidad Innata, Programa Disciplinario de Inmunología, Instituto de Ciencias Biomédicas (ICBM), Facultad de Medicina, Universidad de Chile, Independencia 1027, Santiago, Chile. Phone: 56-2-978-6725; Fax: 56-2-735-3346; e-mail: mhermoso@med.uchile.cl 
identified in a mouse strain that is unresponsive to LPS (3). These studies have made innate immunity a very attractive field of research.

In this review, we will show the mechanisms by which innate immunity is activated through TLRs and connects to adaptive immune responses. We will first describe the TLR characteristics related to bacterial and viral recognition, then how TLR signaling pathways are activated and which are the intracellular regulators and regulatory receptors involved in this process. Finally, an analysis of their participation and relevance in diseases will be detailed.

\section{TOLL-LIKE RECEPTORS}

Activation of innate immunity is a crucial step in antigen-specific acquired immunity development. The primary response to pathogens in the innate immune system is triggered by Pattern Recognition Receptors (PRRs) that bind Pathogen- Associated Molecular Patterns (PAMPs), found in a broad type of organisms. Among the most important families of PRRs are the TLRs which recognize, with selectivity, a large number of varied and complex PAMPs.

Seventeen years ago, the first Toll genes were discovered in Drosophila, associated to dorsal-ventral embryonic polarity (4). The Drosophila Toll protein codifies a transmembrane protein homologue to the interleukin-1 receptor (IL-1R), Toll/IL-1R (TIR) domain (5). Further studies showed that Toll has an essential role in the innate immune response, as mutation of any protein involved in TLR signaling pathway decreases survival after fungal infection (1).

Different human homologues of Drosophila Toll protein were identified; nowadays 11 TLRs have been identified in mammals (6). TLRs are evolutionarily conserved proteins that also have a highly conserved intracellular TIR domain involved in protein-protein interaction and signaling activation. The extracellular domain, with Leucine-rich repeats (LRRs), is related to ligand recognition. LRR motifs vary among TLRs, although how they can discriminate between different PAMPs still remains unclear.

TLR 1, 2 and 6. One of the most studied TLRs is TLR2, that recognizes PAMPs from Gram-positive bacteria, including lipoproteins, lipopeptides, peptidoglycans and lipoteichoic acid, but also lipoarabinomannan from mycobacteria (7), phenol-soluble modulin from Staphylococcus (8), zymosan from fungi (9) and glycosylphosphatidylinositol from Trypanosoma cruzi (10). It remains unclear how a single receptor can recognize such a broad diversity of stimuli. A possible explanation is the association between TLR1 and TLR6 which were demonstrated to form heterodimeric complexes with TLR2 (Figure 1) $(11,12)$. TLR6 association with TLR2 induced recognition of diacylated lipopeptide (11) but TLR1-TLR2 heterodimer binds preferentially triacylated lipopeptides (12), and this discrimination might be related to the LRR domain topology (13), a unique property for TLR2.

Fungal recognition may involve TLR2 association with members of the lectin receptor family, that may enhance its activation by $\beta$-Glucan ligands (14).

Surprisingly, TLR2 expression and activity have been shown to be cooperatively regulated by pro- and anti-inflammatory molecules, such as tumor necrosis factor $\alpha$ $(\mathrm{TNF} \alpha)$ and glucocorticoids, respectively (15), contrary to reports in relation to glucocorticoids that classically counteract expression of adaptive immune molecules. These observations encouraged the authors to study the intracellular mechanisms that may account for the synergic response to pro- and anti-inflammatory molecules observed on the innate immune response mediated through TLR2 (16).

TLR 4. TLR 4 importance in innate immune response was initially demonstrated in $\mathrm{C} 3 \mathrm{H} / \mathrm{HeJ}$ and $\mathrm{C} 57 \mathrm{BL} /$ $10 \mathrm{ScCr}$ mice strains that are resistant to endotoxic shock, by presenting a mutation in TLR4 gene (3).

This receptor is essential for LPS detection but, like TLR2, TLR4 recognizes other molecules from different origins, including some agonists derived from 
plants. TLR4 can also recognize taxol (a strong antitumor agent in humans) derived from Taxus brevifolia (17), and a respiratory syncytial virus fusion protein (18). Furthermore, TLR4 is activated by endogenous ligands, such as heat shock protein 60 (HSP60), HSP70, fibronectin, hyaluronic acid, fibrinogen and heparan sulfate.

LPS recognition by TLR4 requires the formation of a protein complex containing accessory molecules: LPS is generally bound to LPS-binding protein (LBP) present in the serum, this complex is firstly recognized by CD14 receptor (Figure 1), strongly expressed in peripheral blood monocytes and macrophages (19). Once bound to CD14, LPS comes in close proximity with TLR4; however the efficient triggering of an inflammatory response requires the expression of the secreted protein MD-2 (Figure 2) (19).

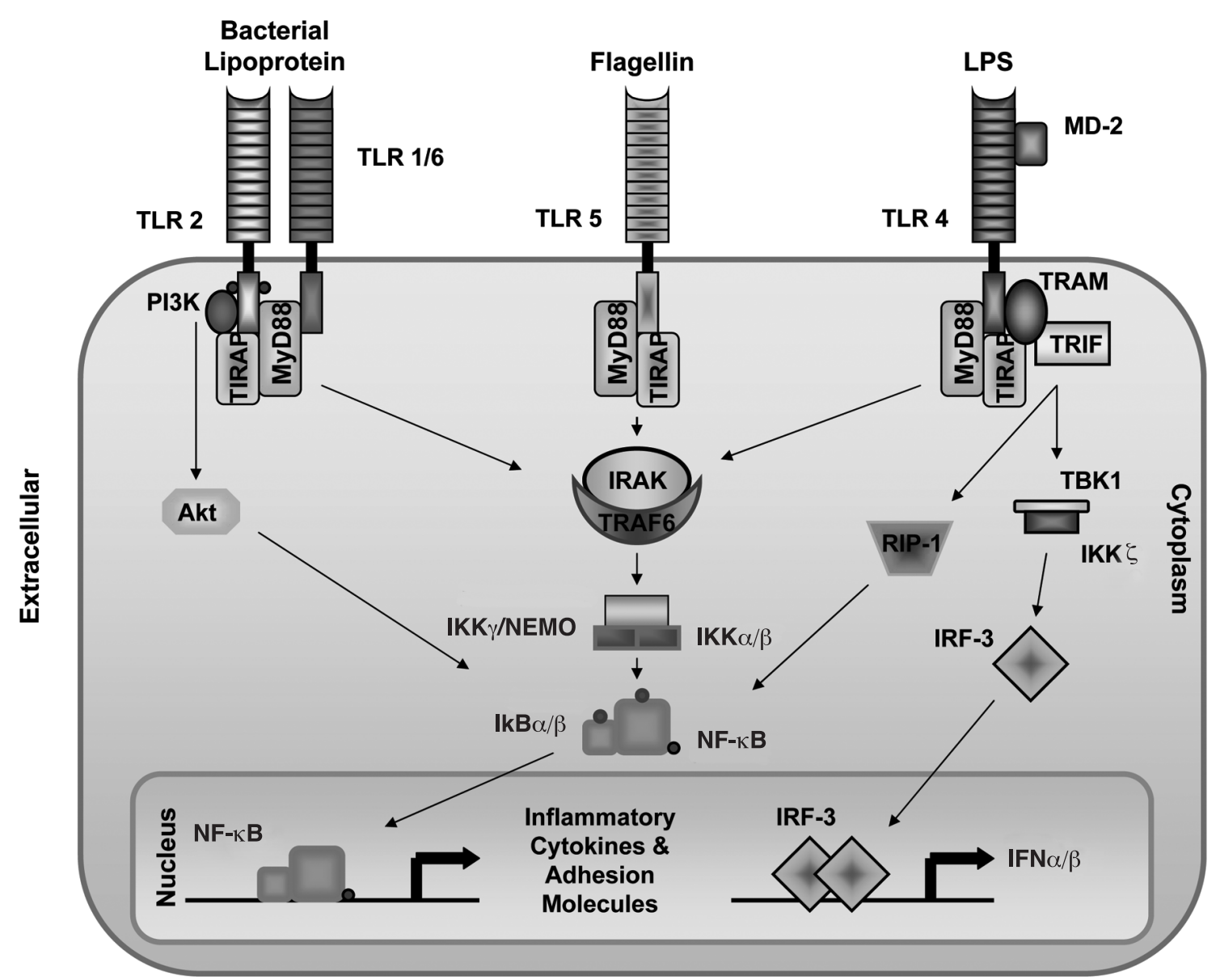

Figure 1: TLR signaling activation by bacterial ligands. When TLR2, 4 and 5 are activated, MyD88 is recruited to the TLR/TIR domain to induce pro-inflammatory cytokine production through a classical signaling pathway. In this pathway the IKK family of proteins is activated in a process that involves IRAK-1 and TRAF6. The IKK complex catalyzes IKB $\alpha$ phosphorylation and degradation by the proteasome, therefore allowing NFKB to translocate into the nucleus. Once in the nucleus, NFKB regulates the expression of pro-inflammatory cytokines and adhesion molecules. In addition, TLR2 and 4 uses a MyD88-independent pathway that involves PI3K and TRIF recruitment to the TLR/TIR domain. TLR4 activates a TRIF-dependent pathway that induces the activation of IRF-3 and subsequently the production of type I IFN in response to LPS. 


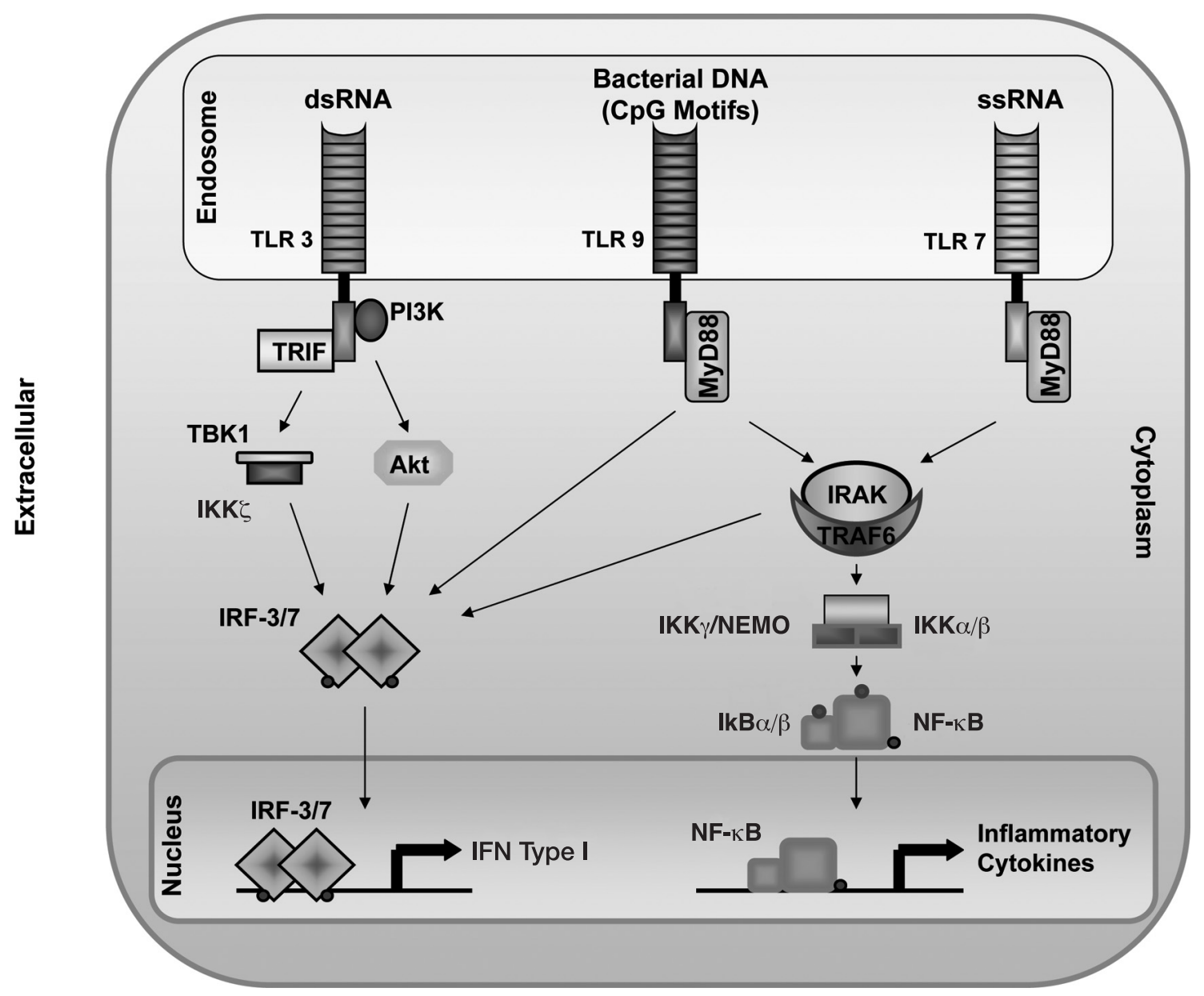

Figure 2: TLR signaling activation by viral PAMPs. During viral recognition in the endosome, TLR7, 8 and 9 use the cytoplasmic adaptor molecule, MyD88. However, TLR3 triggers a TIR domain-containing adaptor inducing IFN- $\beta$ (TRIF) signaling pathway independent of MyD88 recruitment. The MyD88-dependent pathway induces the phosphorylation and proteasomic

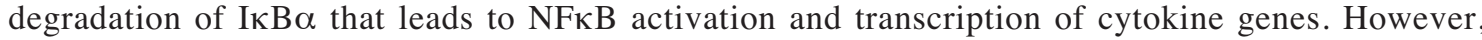
TLR9, 7 and 8 can activate and regulate IFN $\alpha / \beta$ production through a MyD88-dependent pathway by using different interferon regulatory factors (IRFs). TLR3 can also regulate IFN $\alpha / \beta$ production by IRFs, through a TRIF-dependent pathway that may also involve PI3K or TBK1/IKK-epsilon activation.

In humans, a number of polymorphic alleles of TLR 4 have been identified, that have been related to an increased susceptibility to develop diseases, such as Crohn's disease and septic shock (20).

TLR 5. The flagellum is a complex structure required for bacterial motility and is composed among others by the protein flagellin. TLR5 recognizes a flagellin portion derived from Gram-positive and negative bacteria (21). This protein region induces inflammatory mediators, such as TNF $\alpha$ and IL-8 in epithelial cells (22). Recent studies show that the TLR5 allele polymorphism 392STOP abolishes flagellin signaling and has been associated with Legionella pneumophila pneumonia (23).

TLR3, TLR7, TLR8 and TLR9. Adequate host defense against viral infections involves rapid pathogen recognition by TLR3, TLR7, TLR8 and TLR9 among other PRRs. The viral PAMPs 
recognized by these receptors include: double-stranded RNA (dsRNA), singlestranded RNA (ssRNA) and doublestranded DNA (dsDNA) (24-26). TLR7 and TLR8 recognize viral and non-viral ssRNA and activate cytokine production through interferon regulatory factor 3 (IRF3) and IRF7 (Figure 2) $(27,28)$. TLR7 responds to ssRNA producing interferon type I (IFN type I) and pro-inflammatory cytokines (2931). TLR7 is highly expressed in plasmocytoid dendritic cells (pDC), specialized in IFN type I $(\alpha / \beta$ IFN) production against viral infections $(27,32)$.
TLR7, 8 and 9 are closely related phylogenetically and, together with TLR3, they are distributed in endosomal compartments exposing the TIR domain toward the cytoplasm. For cellular activation, these TLRs require ligand internalization to the endosome (33) and activation of intracellular signaling pathways that involve IRFs that lead to $\alpha / \beta$ IFN production (31, 32, 34-36). Proinflammatory pathways and the expression of co-stimulatory molecules are activated by viral PAMPs in antigen presenting cells (APCs).

Virus, Bacteria and Fungi

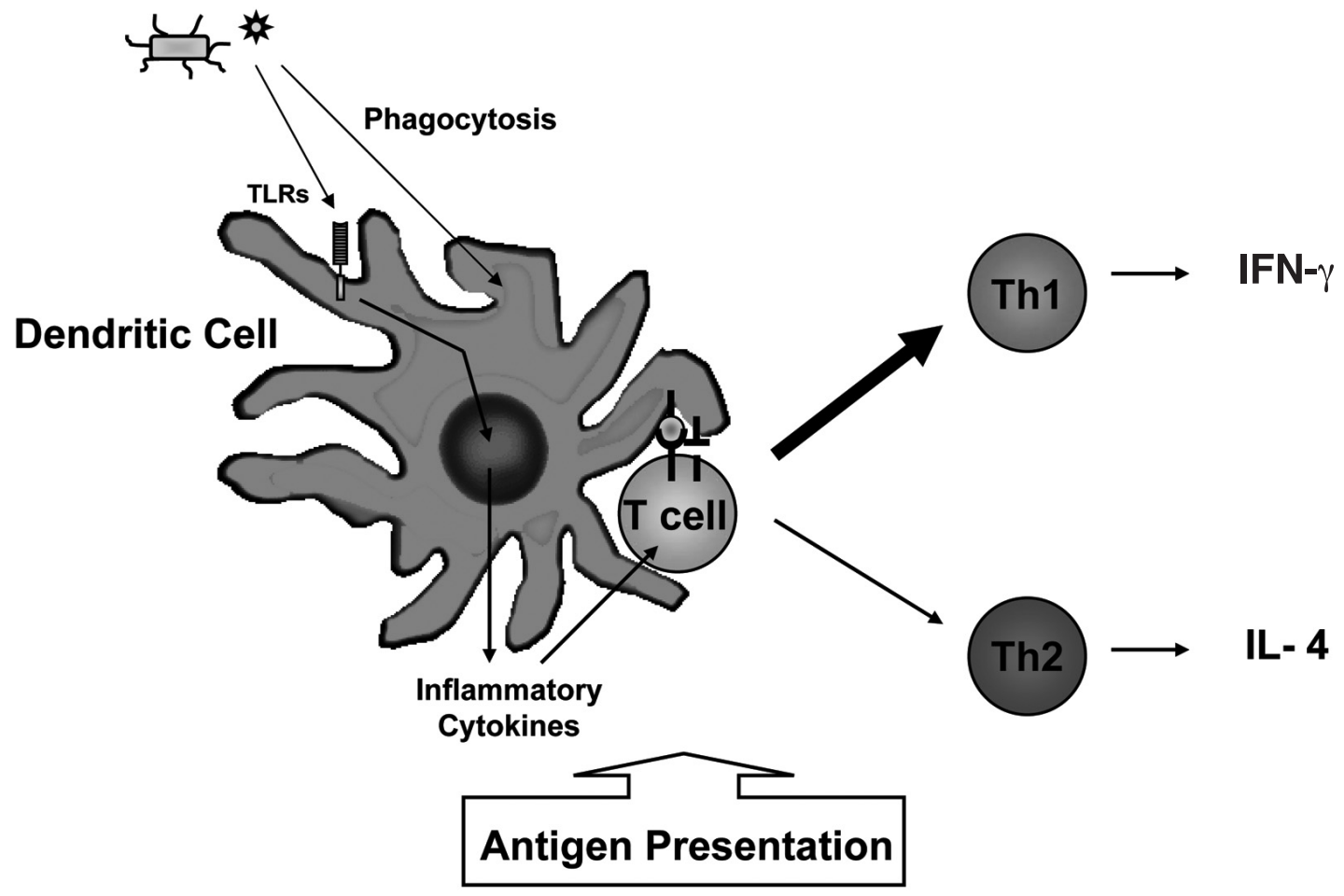

\section{Innate Immunity}

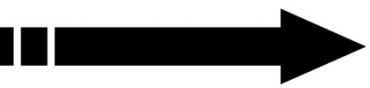

\section{Acquired Immunity}

Figure 3: Innate immunity is the first line of defense against pathogens. To prevent infection, the innate immune response activates adaptive immune processes through TLRs and antigen presentation. Dendritic cells and macrophages recognize and phagocytose pathogens that promote cytokine expression and antigen presentation through the major histocompatibility complex (MHC). $\mathrm{T}$ Cells are activated and differentiated by cytokines and antigen presentation to $\mathrm{TH} 1$ or $\mathrm{TH} 2$ immune patterns, regulating the adaptive immune responses. 
The IFN type I pathway plays a central role in antiviral host response as its activation leads to increased interferon stimulated genes (ISGs) expression, thus promoting an antiviral state $(24,37,38)$.

Currently, it is proposed that TLR3 may have a potential role in the cross- priming process in $\mathrm{CD} 8+$ cell responses to virus infected dendritic cells (39).

TLR8 is mainly expressed in myeloid dendritic cells ( $\mathrm{mDC}$ ) and in macrophages and its activation by ssRNA induces proinflammatory cytokines in a MyD88dependent manner (40).

TLR9 senses DNA from Murine Cytomegalovirus (MCMV) $(41,42)$ and Herpes Simplex virus 1 and 2 (HSV 1 and HSV 2) $(36,43)$.

\section{TLR SIGNALING}

\section{MyD88-dependent pathway}

Almost all TLRs have a common signaling pathway, in which adaptor molecules forming a molecular complex with TIR domain initiate signaling events.

TLRs activation firstly recruits MyD88, a common adaptor protein that is fundamental in the innate immune response activation (Figure 1 and 2). MyD88 has a C-terminal TIR containing portion (residues 155-296) that associates to the TLR- TIR domain (44). MyD88 N-terminal corresponds to a death domain (DD), that mediates interactions with other DD-containing proteins (45). MyD88DD has been implicated in TLR-induced cell death (46). Interestingly, data from our laboratory have shown that MyD88 has canonical nuclear localization and export motives that may be involved in protein nuclear-cytoplasmic transit that may have an impact in cell death when TLR2 is activated (47). MyD88 also has an intermediate domain (ID) that is crucial in TLR signaling as it interacts with IL-1R associated kinase (IRAKs).

Another adaptor factor in TLR signaling closely related to MyD88 is the TIR domain-containing adaptor protein/MyD88adaptor-like (TIRAP/Mal) (48). TIRAPdeficient mice have an impaired production of cytokines and activation of $\mathrm{NF \kappa B}$ and activating protein-1 (AP-1) when TLR 2 and 4 are activated $(49,50)$, making TIRAP a crucial regulatory step in innate immune pro-inflammatory responses.

Downstream from MyD88 the IRAK proteins transduce signaling events. The IRAK family is formed by serine/threonine kinases, of which four members have been described: IRAK-1, IRAK-2, IRAK-4 and IRAK-M. Each protein contains a DD in its $\mathrm{N}$-terminus and a kinase domain at the central portion. IRAK-1 and IRAK-4 have auto- and cross-phosphorylation kinase activity, and IRAK-2 and IRAK-M are inactive proteins, as they lack an aspartic acid residue in the kinase domain (51). As predicted, IRAK-4 -/- mice are resistant to LPS, demonstrating its important role in TLR4 signaling regulation (52).

All IRAK proteins, except IRAK-4, contain a TRAF-binding motif, suggesting that IRAK-4 indirectly interacts with TRAF6 (TNF receptor associated factor 6) (53). TRAF proteins have an N-terminal zinc-binding domain, and a C- terminal domain that leads to self-association and interaction with receptors and signaling proteins. TRAF6 regulates distinct processes of innate and adaptive immunity, mediated by IKB kinases (IKK) and mitogen-activated protein kinases (MAPK) that regulate $\mathrm{NFKB}$ and $\mathrm{AP}-1$ transcription factors. However, how IKKs and MAPK are activated by TRAF6 still remains unclear (54-56).

Another signaling pathway activated downstream from MyD88 and TRAF6 is the formation of the IRF7 complex when a ssRNA or CpG-DNA motif from either viruses or bacteria binds to TLR7 or TLR9, respectively; all these events conduce to the activation of IFN type I transcription (27).

A crucial event in pro-inflammatory signaling activation is the interaction of IRAK-4 with MyD88-ID domain that promotes, after recruitment to the receptor TIR domain, the phosphorylation of IRAK1. Once IRAK-1 is phosphorylated TRAF6 is recruited to the TLR complex. Finally IRAK-1 and TRAF6 dissociate from the TIR/MyD88/IRAK-4 complex and interact with membrane-associated proteins, such as 
TAK 1 (transforming growth factor- $\beta$ activated kinase 1), TAB 1 (transforming growth factor- $\beta$-activated protein kinase 1 binding protein 1) and TAB2 that are part of the multicomplex IRAK-1-TRAF6-TAK1TAB1-TAB2 (57). When TAK1 and TAB2 become phosphorylated they induce IRAK-1 dissociation from the complex and further IKKs and MAPKs activation (55). Recent studies showed that TRAF6 can bind ubiquitin-conjugating enzymes Ubc13 and Uev1A, that are critical in the activation of TAK1-mediated phosphorylation of IKK and MKK (MAPK Kinases) $(58,59)$. The ubiquitination of TRAF6 mediates NFkB activation through a process that does not require protein degradation (59).

The IKK complex has been reported to be important in the regulation of transcriptional activity through NFKB. This protein complex is formed by two kinases: the IKK $\alpha$ and the IKK $\beta$, where IKK $\alpha$ is crucial for the phosphorylation of $\mathrm{I} \kappa \mathrm{B} \alpha$ mediated by IKK $\beta$ (60). The mechanism by which the IKK complex induces NFKB activation involves the phosphorylation of $\mathrm{I} \kappa \mathrm{B} \alpha$ in a serine residue followed by its proteasomic degradation, allowing $\mathrm{NF \kappa B}$ nuclear translocation and the expression of pro-inflammatory cytokines and adhesion molecules .

\section{MyD88-independent pathways}

Some TLR signaling pathways, such as these activated by TLR3 and TLR4, do not use MyD88 as an adaptor protein to trigger innate immune responses. TLR3 and TLR4 expressed in APCs require the TIR domaincontaining adaptor inducing IFN- $\beta$ (TRIF) protein to induce $\mathrm{NF \kappa B}$ activation and interferon and co-stimulatory molecule expression (61).

TLR4 activation by LPS may induce the expression of the TRIF-related adaptor molecule (TRAM/TICAM-2) that binds to TLR4 and to TRIF. TLR4 utilizes the adaptors TRIF and TRAM independently of $\mathrm{Mal}$ and MyD88 to initiate the late phase of $\mathrm{NF \kappa B}$ activation and also to induce the expression of IFN- $\beta$ and other IFNinducible genes via the transcription factor
IRF-3 (Figure 1) (61, 62). TRAM, like Mal, acts as a bridge to couple TRIF to TLR4 and is absolutely required for TLR4 mediated responses. TRAM-/- mice are completely impaired in their responses to LPS while Mal or MyD88 deficient mice do respond albeit with delayed kinetics $(49,50)$.

When TLR3 signaling pathway is activated by viral dsRNA, TRIF is recruited to the receptor and induces IFN type I through TRIF-IKK-epsilon (Figure 2). Furthermore, agonist activation of TLR3 may promote tyrosine phosphorylation that allows phosphatidylinositol 3-kinase (PI3K) recruitment, Akt activation and finally IRF3 phosphorylation (63). TLR3 can, in addition, stimulate pro- inflammatory cytokine expression by connecting the TRIF downstream signaling molecule to NFKB activation (Figure 2) (64).

\section{NEGATIVE REGULATORS OF TLRS}

Pathogen recognition through TLRs always induces pro-inflammatory cytokine expression (65). A balance between TLR activation and inactivation is crucial to avoid an excessive inflammatory response, as occurs in autoimmune, chronic inflammatory and infectious diseases. TLR pathway activation may be regulated by several molecules that keep a balance between health and disease, involving extra- and intracellular regulators, as well as regulatory receptors.

\section{EXTRACELLULAR REGULATORS}

Soluble forms of TLR have been reported as extracellular regulators of proinflammatory response that trigger innate immunity.

The soluble form of TLR2, sTLR2, is produced by a post-translational modification of the anchored TLR2 that is constitutively expressed in blood monocytes, and found in human plasma and milk. Inhibition of sTLR2 splice variant expression increases cellular response to bacterial lipopeptide (66)

The soluble product sTLR4 is an alternative splice variant of TLR4 that was 
shown to be expressed as a mechanism to inhibit LPS-mediated TNF $\alpha$ production and NFKB activation (67), blocking MD-2 recruitment to the TLR4-CD14 complex.

Finally, a soluble form of TLR5 (TLR5s) has been described in fish and it is involved in the response of flagellin that induces an increased NFKB activation by a cellular mechanism that is not completely understood (68).

\section{INTRACELLULAR REGULATORS}

Several intracellular adaptors and kinases have been reported to endogenously regulate the expression of pro-inflammatory molecules upon the activation of TLRs.

The splice variant form of MyD88, MyD88s, encodes a protein that lacks the ID and is constitutively expressed in spleen. MyD88 can be induced in monocytes by long term exposure to LPS (69). The mechanism by which MyD88s reverts inflammation involves IRAK-4 sequestration by MyD88s that prevents further phosphorylation of IRAK-4 and IRAK-1 and activation of NFkB (70). MyD88s does not prevent AP-1 activation, indicating that MAPK activation is part of an independent pathway that diverges from MyD88 signaling (71).

IRAK-M is another negative regulator of the TLR pathway, and together with IRAK2 , they are the members of the IRAK family without catalytic activity. IRAK-M expression has been reported to be restricted to monocytes and macrophages. IRAK- 2 and IRAK-M can reconstitute IL-1 response in the 293 cell line that does not endogenously express IRAKs (72). IRAK$M$ and IRAK-2 block pro-inflammatory cytokine expression by dissociating the complex formed by MyD88-IRAK-1/-4 and IRAK-TRAF6. IRAK-M -/- mice show an over-production of inflammatory cytokines in response to LPS and bacterial DNA-like CpG motifs (73), suggesting that IRAK-M plays an important role in regulating the MyD88-dependent signaling pathway.

The suppressor of cytokine signaling proteins, SOCS, are a family of 8 proteins that are induced by cytokines. SOCS1 and
SOCS3 are relevant members that regulate the TLR4/NFKB signaling pathway in macrophages (74). Macrophages from SOCS3 $^{-/-}$mice exposed to IL-10 and IL-6 showed suppression in LPS-induced TNFa production (75).

PI3K has been also implicated in TLRs signaling (76), suppressing both MAPKs and NFKB in response to LPS, thereby decreasing TNF $\alpha$ production (77). PI3K regulates immune responses by blocking IL12 and limiting TH1 polarization (76). PI3K is an enzyme that catalyzes the phosphorylation of phosphatidylinositol 4,5bisphosphate (PIP2) to phosphatidylinositol 3,4,5-trisphosphate (PIP3). PI3K is composed of a p85 regulatory subunit and a p110 catalytic subunit. PI3K usually is recruited to phosphorylated tyrosine residues within YXXM motifs through SH2 domains. Stimulation of TLR2 expressing cells with Staphylococcus aureus promotes PI3K recruitment to the TIR domain and induces transactivation of the NFKB subunit p65 by a mechanism that seems to be independent of I $\kappa \mathrm{B} \alpha$ proteasomic degradation (78). In neutrophils stimulated with peptidoglycan, that activates TLR2 signaling pathways, and concomitantly with a PI3K inhibitor, the TNF $\alpha$ secretion and p65 transactivation were greatly reduced (79). Altogether these findings indicate that PI3K seems to participate in pro- or anti-inflammatory immune responses depending on the cell type and the TLR2 stimulus used.

The Toll-interacting protein (Tollip) is another inhibitory adaptor molecule that was firstly identified as an intermediate in IL-1R signaling pathway (80). Tollip is recruited to the TIR domain and decreases IRAK-1 phosphorylation upon LPS activation. IRAK-1 activation by MyD88 promotes Tollip dissociation from the TIR domain (81). It has been shown that PI3K regulates the inhibitory effects of Tollip, by interacting with 3 'phosphorylated phosphatidylinositides (82).

Nucleotide oligomerization domain receptor (NOD2) is a mammalian cytosolic PRR, and polymorph variants have been associated to Crohn's disease (CD) (83). NOD2 protein is constituted by two caspase recruitment domains (CARD), a NOD 
region and a tripartite domain, consisting of a C-terminal LRR. This last domain recognizes and reacts to the bacterial component muramyl dipeptide (MDP), and is the site with major genetic variability $(84,85)$. NOD2 variants that are associated with CD, do not respond to MDP stimulation (86).

NOD2 -/- macrophages stimulated with TLR2 agonists respond to peptidoglycan (PGN) by releasing high levels of interleukin-12 (IL-12) and increasing NFKB activation. On restoring the NOD2 phenotype, NFKB activation and IL-12 expression are lower, concluding that NOD2 is a negative regulator of TLR2 (87).

\section{REGULATORY RECEPTORS}

ST2 is a member of the Toll/IL-1R protein family, that also regulates the TLR proinflammatory pathway (88). ST2 was originally identified as a gene induced by serum or oncogenes in mouse fibroblasts (89). Three distinct ST2 gene products, generated by alternative splicing have been described: a soluble secreted form (ST2s), a transmembrane receptor form (ST2L), and a variant form (ST2v) (90- 92). ST2s is constitutively expressed in hematopoietic and non-hematopoietic cells (93), ST2L in TH2 lymphocytes but not TH1 cells (94, 95), and ST2v in intestinal cells (90).

ST2s behaves as immune modulator in in vitro and in vivo assays by using anti-ST2 antibodies or a recombinant ST2s protein (9698). ST2L is a type I transmembrane protein with three extracellular immunoglobulin-like domains and an intracellular TIR domain. ST2L can drive MAPK activation, but it also downregulates NFKB activation in response to IL-1 or LPS stimulation (61). A possible mechanism for ST2L immune modulation involves its interaction with molecular adaptors of TLR/IL-1 inflammatory pathways. ST2L can sequestrate MyD88 and Mal through their TIR domains, and therefore can block the effect of TLR4-mediated NFKB activation (99).

Recently IL-33, a member of the IL-1 family, was reported to block NFKB and MAPKs activation through ST2L. IL-33 drives anti-inflammatory $\mathrm{TH} 2$ - associated cytokine production from in vitro polarized TH2 cells (100).

The negative regulation of ST2s is different to that described for ST2L. In proinflammatory conditions and asthma ST2s is up-regulated $(93,101)$; although the mechanism of action is currently unknown, ST2s can induce anti-inflammatory effects by diminishing TH1 pro-inflammatory cytokines. Moreover, in LPS-activated macrophages, ST2s downregulates TLR4 mRNA expression (96).

SIGIRR (single Immunoglobulin IL-1Rrelated molecule or TIR8) is a negative regulator of the IL-1R and TLR4 pathways that does not affect NFKB and AP-1 activation (102). SIGIRR interacts with IL$1 \mathrm{R}$ and TLR4 in a ligand-dependent manner and inhibits their signaling $(102,103)$. SIGIRR is a member of the Interleukin-1 receptor (IL-1R) family. SIGIRR has one immunoglobulin domain in the extracellular structure and a long TIR cytoplasmic domain, both segments being involved in the IL-1R/TLR4 response inhibition $(103,104)$.

\section{TLR AND ITS RELEVANCE IN HUMAN DESEASE}

TLRs are vital players in infectious and inflammatory diseases. Mainly because of their influence in adaptive immunity activation, manipulation of TLR signaling is a potential and up-to-date therapeutic target for diverse human diseases.

Much of the knowledge about TLR function in human disease is based on analysis of individuals with $T L R$ gene polymorphisms (105). Among these, the role of the TLR4 polymorphism Asp299Gly in sepsis caused by Gram-negative bacteria but not by polymicrobial agents particularly important (106). The allele 299Gly has been also linked to severe bronchiolitis generated by respiratory syncytial virus that also activates the TLR4 pathway (84). Exposure to LPS exacerbates preexisting asthma severity (probably by increasing airway inflammation) but, paradoxically, it decreases asthma incidence later in life, and also atopy severity $(105,107,108)$. Allelic 299Gly polymorphism also has a protective 
role in rheumatoid arthritis (109), Crohn's disease and ulcerative colitis development (110), among other diseases.

Other TLR polymorphisms with clinical relevance include: TLR2 Arg753Gln, which predisposes to staphylococcal infections (111) and tuberculosis (112), and TLR5 common stop codon (392STOP) that results in decreased flagellin signaling and increased susceptibility to Legionella pneumophila (23).

TLRs have been also implicated in allergic reactions with a $\mathrm{TH} 2$ immune pattern; it has been postulated that LPS at very low doses promotes a $\mathrm{TH} 2$ response through a MyD88-independent pathway, but at infective doses, LPS leads to a TH1 response (113). Based on these findings and the ability of R-848 (resiquimod), a synthetic TLR7 and TLR8 ligand, to shift to a $\mathrm{TH} 1$ response, it is actually used to transform a characteristic TH2 into a protective TH1 response (114).

Although early-response cytokines play an important role in host defense, their entry into the systemic circulation can bring about a widespread microvascular injury. Certain TLRs such as TLR2, TLR4 and TLR6, are expressed in cardiomyocytes and may play a critical role in cardiovascular collapse pathogenesis that occurs during sepsis. Signaling via TLR4 in cardiomyocytes is supposed to be responsible, at least in part, for production of mainly TNF $\alpha$, IL- $1 \beta$ and nitric oxide, leading to heart damage and left ventricular dysfunction (115-118).

The role of TLRs in viral disease progression is not yet completely elucidated. Certain viral proteins that directly bind to TLRs could be important therapeutic targets able to suppress or activate receptor signaling in diverse clinical contexts. Host defense against virus involves IFN type I production that leads to IFN-stimulated gene expression, with the resulting activation of antiviral, antiproliferative and immunoregulatory responses (119). Among others, herpes simplex virus has been shown to induce IFN type I production by plasmocytoid dendritic cells through a mechanism that involves TLR9 activation (43, 120). Induction of TLR9-mediated mucosal innate immunity by specific receptor agonists could provide protection against these viruses (25). To date, synthetic TLR7 and TLR8 agonists such as imiquimod, have been found to be a useful treatment for viral pathogens and skin cancers (121).

Cancer has been linked to innate immunity, as tumors can be eradicated in conditions where the local environment resembles an infection (113). In this context, murine models have been used to investigate the role of $\mathrm{CpG}$ oligodeoxyribonucleotides as immunotherapeutic agents against various solid tumors including colon carcinoma (122) and lymphoma (123).

Systemic autoimmune diseases, such as rheumatoid arthritis (RA) and systemic lupus erythematosus (SLE) are characterized by production of auto- antibodies. During the last years, an unexpected role for TLRs in triggering $\mathrm{B}$ cells to produce rheumatoid factor (RF) has been described. B cells were shown to be activated by a mechanism that seems to be independent from $\mathrm{T}$ cell activation and appears to be mediated by TLR9, which is restricted in humans to B cells and plasmocytoid dendritic cells (124). IgG2a-chromatin immune complex activates RF- specific B cells by a dual engagement of the antigen receptor and TLR9 (125). In SLE numerous auto-antibodies are generated, and the recognition of unmethylated CpG-DNA by TLR9 raises the question of the receptor's role in the disease pathogenesis. The presence of unmethylated CpG-DNA in immune complexes may promote their intracellular uptake and activation of endosomal TLR9 leading to proinflammatory responses that can be related to the SLE activity seen during recurrent microbial infections (126-128). If impaired tolerance to self DNA turns out to involve TLR9 then, TLR9 antagonists emerge as interesting potential therapeutic tools against SLE.

Various dermatological disorders have been also linked to impaired innate immune responses. Normal keratinocytes express TLR1, TLR2 and TLR5, switching their TLR pattern expression as they mature (129). TLR2 and TLR4 expression in normal cultured human keratinocytes, increases in response to LPS plus IFN- $\gamma$, 
Candida albicans, mannan and Mycobacterium tuberculosis (100, 130). Among others, psoriasis and acne vulgaris are two prevalent dermatological diseases in which TLR may play an important pathogenic role. In psoriasis, a chronic inflammatory skin disease characterized by a TH1-type cytokine profile, TLR2 has been found to be strongly expressed in upper epidermis of psoriatic plaques, whereas in normal and non-lesional skin, it appears to be more highly expressed in the basal layers (129). The study of distinctive TLR and heat-shock protein expression patterns by specific cell subsets in normal and psoriatic skin shows a stronger and more diffuse TLR 1 expression in basal psoriatic keratinocytes (131). In acne vulgaris, TLR2 is expressed at the site of disease, indicating that the associated inflammation is triggered by the receptor's activation $(121,132)$.

The ability to appropriately respond to pathogenic assault is critical to survival, and the TLRs are the first point of contact that we have with invading organisms. The mechanisms regulating the TLR response must be controlled tightly, first to respond properly to the pathogenic challenge and second, to avoid excessive activation of the TLR signaling pathway and thus, to control damaging injury to the host system following TLR activation. The complex mechanisms by which TLR signaling may be regulated are emerging in the literature. Ultimately, better understanding of the mechanisms behind TLR activation will hopefully lead to the development of novel therapeutic strategies in the treatment of inflammatory diseases and autoimmunity.

\section{ACKNOWLEDGMENTS}

We thank E. Medlin and C. Arancibia for critically revising the manuscript and Dr. A. Göecke for constructive discussion.

\section{REFERENCES}

1. LEMAITRE B, NICOLAS E, MICHAUT L, REICHHART JM, HOFFMANN JA 1996 The dorsoventral regulatory gene cassette spatzle/Toll/ cactus controls the potent antifungal response in Drosophila adults. Cell 86: 973-83

2. MEDZHITOV R, PRESTON-HURLBURT P JANEWAY CA, JR 1997 A human homologue of the Drosophila Toll protein signals activation of adaptive immunity. Nature 388: 394-7

3. POLTORAK A, HE X, SMIRNOVA I, LIU MY, VAN HUFFEL C, DU X, BIRDWELL D, ALEJOS E, SILVA M, GALANOS C, FREUDENBERG M, RICCIARDI-CASTAGNOLI P, LAYTON B, BEUTLER B 1998 Defective LPS signaling in C3H/ $\mathrm{HeJ}$ and $\mathrm{C} 57 \mathrm{BL} / 10 \mathrm{ScCr}$ mice: mutations in Tlr4 gene. Science 282: 2085-8

4. HASHIMOTO C, HUDSON KL, ANDERSON KV 1988 The Toll gene of Drosophila, required for dorsal-ventral embryonic polarity, appears to encode a transmembrane protein. Cell 52: 269-79

5. GAY NJ, KEITH FJ 1991 Drosophila Toll and IL-1 receptor. Nature 351: 355- 6

6. ZHANG D, ZHANG G, HAYDEN MS, GREENBLATT MB, BUSSEY C, FLAVELL RA, GHOSH S 2004 A toll-like receptor that prevents infection by uropathogenic bacteria. Science 303: 1522-6

7. WIELAND CW, KNAPP S, FLORQUIN S, DE VOS AF, TAKEDA K, AKIRA S, GOLENBOCK DT, VERBON A, VAN DER POLL T 2004 Non-mannosecapped lipoarabinomannan induces lung inflammation via toll-like receptor 2. Am J Respir Crit Care Med 170: $1367-74$

8. OZINSKY A, UNDERHILL DM, FONTENOT JD, HAJJAR AM, SMITH KD, WILSON CB, SCHROEDER L, ADEREM A 2000 The repertoire for pattern recognition of pathogens by the innate immune system is defined by cooperation between toll-like receptors. Proc Natl Acad Sci U S A 97: 13766-71

9. SATO M, SANO H, IWAKI D, KUDO K, KONISHI M, TAKAHASHI H, TAKAHASHI T, IMAIZUMI H, ASAI Y, KUROKI Y 2003 Direct binding of Toll-like receptor 2 to zymosan, and zymosan-induced NFkappa $\mathrm{B}$ activation and TNF-alpha secretion are downregulated by lung collectin surfactant protein A. J Immunol 171: 417-25

10. CAMPOS MA, ALMEIDA IC, TAKEUCHI O, AKIRA S, VALENTE EP, PROCOPIO DO, TRAVASSOS LR, SMITH JA, GOLENBOCK DT, GAZZINELLI RT 2001 Activation of Toll-like receptor-2 by glycosylphosphatidylinositol anchors from a protozoan parasite. J Immunol 167: 416-23

11. TAKEUCHI O, KAWAI T, MUHLRADT PF, MORR M, RADOLF JD, ZYCHLINSKY A, TAKEDA K, AKIRA S 2001 Discrimination of bacterial lipoproteins by Toll- like receptor 6. Int Immunol 13: 933-40

12. TAKEUCHI O, SATO S, HORIUCHI T, HOSHINO K, TAKEDA K, DONG Z, MODLIN RL, AKIRA S 2002 Cutting edge: role of Toll-like receptor 1 in mediating immune response to microbial lipoproteins. J Immunol 169: 10-4

13. OMUETI KO, BEYER JM, JOHNSON CM, LYLE EA, TAPPING RI 2005 Domain exchange between human toll-like receptors 1 and 6 reveals a region required for lipopeptide discrimination. J Biol Chem 280: $36616-25$

14. GANTNER BN, SIMMONS RM, CANAVERA SJ, AKIRA S, UNDERHILL DM 2003 Collaborative induction of inflammatory responses by dectin-1 and Toll-like receptor 2. J Exp Med 197: 1107-17

15. HERMOSO MA, MATSUGUCHI T, SMOAK K, CIDLOWSKI JA 2004 Glucocorticoids and tumor 
necrosis factor alpha cooperatively regulate toll- like receptor 2 gene expression. Mol Cell Biol 24: 4743-56

16. SHUTO T, IMASATO A, JONO H, SAKAI A, XU H, WATANABE T, RIXTER DD, KAI H, ANDALIBI A, LINTHICUM F, GUAN YL, HAN J, CATO AC, LIM DJ, AKIRA S, LI JD 2002 Glucocorticoids synergistically enhance nontypeable Haemophilus influenzae-induced Toll-like receptor 2 expression via a negative cross-talk with p38 MAP kinase. J Biol Chem 277: 17263-70

17. KAWASAKI K, AKASHI S, SHIMAZU R, YOSHIDA T, MIYAKE K, NISHIJIMA M 2000 Mouse toll-like receptor 4.MD-2 complex mediates lipopolysaccharide-mimetic signal transduction by Taxol. J Biol Chem 275: 2251-4

18. KURT-JONES EA, POPOVA L, KWINN L, HAYNES LM, JONES LP, TRIPP RA, WALSH EE, FREEMAN MW, GOLENBOCK DT, ANDERSON LJ, FINBERG RW 2000 Pattern recognition receptors TLR4 and CD14 mediate response to respiratory syncytial virus. Nat Immunol 1: 398-401

19. DA SILVA CORREIA J, SOLDAU K, CHRISTEN U, TOBIAS PS, ULEVITCH RJ 2001 Lipopolysaccharide is in close proximity to each of the proteins in its membrane receptor complex. transfer from CD14 to TLR4 and MD-2. J Biol Chem 276: 21129-35

20. FIGUEROA C, PERALTA A, HERRERA L, CASTRO P, GUTIERREZ A, VALENZUELA J, AGUILLON JC, QUERA R, HERMOSO MA (2006) NOD2/CARD15 and Toll-like 4 receptor gene polymorphism in Chilean patientes with inflammatory bowel disease. Eur Cytokine Netw 17: 125.1340

21. SMITH KD, ANDERSEN-NISSEN E, HAYASHI F, STROBE K, BERGMAN MA, BARRETT SL, COOKSON BT, ADEREM A 2003 Toll-like receptor 5 recognizes a conserved site on flagellin required for protofilament formation and bacterial motility. Nat Immunol 4: 1247-53

22. EAVES-PYLES T, MURTHY K, LIAUDET L, VIRAG L, ROSS G, SORIANO FG, SZABO C, SALZMAN AL 2001 Flagellin, a novel mediator of Salmonella-induced epithelial activation and systemic inflammation: I kappa B alpha degradation, induction of nitric oxide synthase, induction of proinflammatory mediators, and cardiovascular dysfunction. J Immunol 166: $1248-60$

23. HAWN TR, VERBON A, LETTINGA KD, ZHAO LP, LI SS, LAWS RJ, SKERRETT SJ, BEUTLER B, SCHROEDER L, NACHMAN A, OZINSKY A, SMITH KD, ADEREM A 2003 A common dominant TLR5 stop codon polymorphism abolishes flagellin signaling and is associated with susceptibility to legionnaires' disease. J Exp Med 198: 1563-72

24. JEFFERIES CA, FITZGERALD KA 2005 Interferon gene regulation: not all roads lead to Tolls. Trends Mol Med 11: 403-11

25. BOWIE AG, HAGA IR 2005 The role of Toll-like receptors in the host response to viruses. Mol Immunol 42: 859-67

26. BOEHME KW, COMPTON T 2004 Innate sensing of viruses by toll-like receptors. J Virol 78: 7867-73

27. KAWAI T, SATO S, ISHII KJ, COBAN C, HEMMI H, YAMAMOTO M, TERAI K, MATSUDA M, INOUE J, UEMATSU S, TAKEUCHI O, AKIRA S 2004 Interferon-alpha induction through Toll-like receptors involves a direct interaction of IRF7 with MyD88 and TRAF6. Nat Immunol 5: 1061-8

28. MOYNAGH PN 2005 TLR signalling and activation of IRFs: revisiting old friends from the NF-kappaB pathway. Trends Immunol 26: 469-76
29. PHILBIN VJ, IQBAL M, BOYD Y, GOODCHILD MJ, BEAL RK, BUMSTEAD N, YOUNG J, SMITH AL 2005 Identification and characterization of a functional, alternatively spliced Toll-like receptor 7 (TLR7) and genomic disruption of TLR8 in chickens. Immunology 114: 507-21

30. GORDEN KB, GORSKI KS, GIBSON SJ, KEDL RM, KIEPER WC, QIU X, TOMAI MA, ALKAN SS, VASILAKOS JP 2005 Synthetic TLR agonists reveal functional differences between human TLR7 and TLR8. J Immunol 174: 1259-68

31. HEIL F, HEMMI H, HOCHREIN $\mathrm{H}$ AMPENBERGER F, KIRSCHNING C, AKIRA S, LIPFORD G, WAGNER H, BAUER S 2004 Speciesspecific recognition of single- stranded RNA via tolllike receptor 7 and 8. Science 303: 1526-9

32. ITO T, WANG YH, LIU YJ 2005 Plasmacytoid dendritic cell precursors/type I interferon-producing cells sense viral infection by Toll-like receptor (TLR) 7 and TLR9. Springer Semin Immunopathol 26: 221-9

33. WAGNER H 2004 The immunobiology of the TLR9 subfamily. Trends Immunol 25: 381-6

34. DIEBOLD SS, KAISHO T, HEMMI H, AKIRA S, REIS E SOUSA C 2004 Innate antiviral responses by means of TLR7-mediated recognition of singlestranded RNA. Science 303: 1529-31

35. ALEXOPOULOU L, HOLT AC, MEDZHITOV R, FLAVELL RA 2001 Recognition of double-stranded RNA and activation of NF-kappaB by Toll-like receptor 3. Nature 413: 732-8

36. LUND J, SATO A, AKIRA S, MEDZHITOV R, IWASAKI A 2003 Toll-like receptor 9- mediated recognition of Herpes simplex virus-2 by plasmacytoid dendritic cells. J Exp Med 198: 513-20

37. MALMGAARD L 2004 Induction and regulation of IFNs during viral infections. J Interferon Cytokine Res 24: 439-54

38. PERRY AK, CHEN G, ZHENG D, TANG H, CHENG G 2005 The host type I interferon response to viral and bacterial infections. Cell Res 15: 407-22

39. SCHULZ O, DIEBOLD SS, CHEN M, NASLUND TI NOLTE MA, ALEXOPOULOU L, AZUMA YT, FLAVELL RA, LILJESTROM P, REIS E SOUSA C 2005 Toll-like receptor 3 promotes cross-priming to virus-infected cells. Nature 433: 887-92

40. ZAREMBER KA, GODOWSKI PJ 2002 Tissue expression of human Toll-like receptors and differential regulation of Toll-like receptor mRNAs in leukocytes in response to microbes, their products, and cytokines. J Immunol 168: 554-61

41. KRUG A, FRENCH AR, BARCHET W, FISCHER JA, DZIONEK A, PINGEL JT, ORIHUELA MM, AKIRA S, YOKOYAMA WM, COLONNA M 2004 TLR9dependent recognition of MCMV by IPC and DC generates coordinated cytokine responses that activate antiviral NK cell function. Immunity 21: 107-19

42. TABETA K, GEORGEL P, JANSSEN E, DU X, HOEBE K, CROZAT K, MUDD S, SHAMEL L, SOVATH S, GOODE J, ALEXOPOULOU L, FLAVELL RA, BEUTLER B 2004 Toll-like receptors 9 and 3 as essential components of innate immune defense against mouse cytomegalovirus infection. Proc Natl Acad Sci U S A 101: 3516-21

43. KRUG A, LUKER GD, BARCHET W, LEIB DA, AKIRA S, COLONNA M 2004 Herpes simplex virus type 1 activates murine natural interferon-producing cells through toll-like receptor 9. Blood 103: 1433-7

44. HULTMARK D 1994 Macrophage differentiation marker MyD88 is a member of the Toll/IL-1 receptor family. Biochem Biophys Res Commun 199: 144-6 
45. BOLDIN MP, METT IL, VARFOLOMEEV EE, CHUMAKOV I, SHEMER-AVNI Y, CAMONIS JH, WALLACH D 1995 Self-association of the "death domains" of the p55 tumor necrosis factor (TNF) receptor and Fas/APO1 prompts signaling for TNF and Fas/APO1 effects. J Biol Chem 270: 387-91

46. ALIPRANTIS AO, YANG RB, MARK MR, SUGGETT S, DEVAUX B, RADOLF JD, KLIMPEL GR, GODOWSKI P, ZYCHLINSKY A 1999 Cell activation and apoptosis by bacterial lipoproteins through toll-like receptor-2. Science 285: 736-9

47. AGUIRRE I BC, HERMOSO MA 2005 Nuclear Localization of MyD88 and its role in Apoptosis. Presented at VII Latin American Congress of Immunology, Cordoba - Argentina

48. HORNG T, BARTON GM, MEDZHITOV R 2001 TIRAP: an adapter molecule in the Toll signaling pathway. Nat Immunol 2: 835-41

49. HORNG T, BARTON GM, FLAVELL RA, MEDZHITOV R 2002 The adaptor molecule TIRAP provides signalling specificity for Toll-like receptors. Nature 420: 329-33

50. YAMAMOTO M, SATO S, HEMMI $\mathrm{H}$, SANJO $\mathrm{H}$, UEMATSU S, KAISHO T, HOSHINO K, TAKEUCHI O, KOBAYASHI M, FUJITA T, TAKEDA K, AKIRA S 2002 Essential role for TIRAP in activation of the signalling cascade shared by TLR 2 and TLR 4 . Nature 420: 324-9

51. JANSSENS S, BEYAERT R 2003 Functional diversity and regulation of different interleukin-1 receptor-associated kinase (IRAK) family members. Mol Cell 11: 293-302

52. SUZUKI N, SUZUKI S, DUNCAN GS, MILLAR DG, WADA T, MIRTSOS C, TAKADA H, WAKEHAM A, ITIE A, LI S, PENNINGER JM, WESCHE H, OHASHI PS, MAK TW, YEH WC 2002 Severe impairment of interleukin-1 and Tolllike receptor signalling in mice lacking IRAK-4. Nature 416: 750-6

53. LI S, STRELOW A, FONTANA EJ, WESCHE H 2002 IRAK-4: a novel member of the IRAK family with the properties of an IRAK-kinase. Proc Natl Acad Sci U S A 99: 5567-72

54. DADGOSTAR H, CHENG G 1998 An intact zinc ring finger is required for tumor necrosis factor receptorassociated factor-mediated nuclear factor-kappaB activation but is dispensable for c-Jun N-terminal kinase signaling. J Biol Chem 273: 24775-80

55. JIANG Z, NINOMIYA-TSUJI J, QIAN Y, MATSUMOTO K, LI X 2002 Interleukin-1 (IL-1) receptor-associated kinase-dependent IL-1-induced signaling complexes phosphorylate TAK1 and TAB2 at the plasma membrane and activate TAK1 in the cytosol. Mol Cell Biol 22: 7158-67

56. BRADLEY JR, POBER JS 2001 Tumor necrosis factor receptor-associated factors (TRAFs). Oncogene 20: $6482-91$

57. TAKAESU G, NINOMIYA-TSUJI J, KISHIDA S, LI $X$, STARK GR, MATSUMOTO K 2001 Interleukin-1 (IL-1) receptor-associated kinase leads to activation of TAK 1 by inducing TAB 2 translocation in the IL-1 signaling pathway. Mol Cell Biol 21: 2475-84

58. WOOFF J, PASTUSHOK L, HANNA M, FU Y, XIAO W 2004 The TRAF6 RING finger domain mediates physical interaction with Ubc13. FEBS Lett 566: 229-33

59. WANG C, DENG L, HONG M, AKKARAJU GR, INOUE J, CHEN ZJ 2001 TAK1 is a ubiquitindependent kinase of MKK and IKK. Nature 412: 346-51
60. O'MAHONY A, LIN X, GELEZIUNAS R, GREENE WC 2000 Activation of the heterodimeric IkappaB kinase alpha (IKKalpha)-IKKbeta complex is directional: IKKalpha regulates IKKbeta under both basal and stimulated conditions. Mol Cell Biol 20: 1170-8

61. BRINT EK, FITZGERALD KA, SMITH P, COYLE AJ, GUTIERREZ-RAMOS JC, FALLON PG, O'NEILL LA 2002 Characterization of signaling pathways activated by the interleukin 1 (IL-1) receptor homologue T1/ST2. A role for Jun Nterminal kinase in IL-4 induction. J Biol Chem 277: 49205-11

62. OSHIUMI H, SASAI M, SHIDA K, FUJITA T, MATSUMOTO M, SEYA T 2003 TIR- containing adapter molecule (TICAM)-2, a bridging adapter recruiting to toll- like receptor 4 TICAM-1 that induces interferon-beta. J Biol Chem 278: 49751-62

63. SARKAR SN, PETERS KL, ELCO CP, SAKAMOTO S, PAL S, SEN GC 2004 Novel roles of TLR3 tyrosine phosphorylation and PI3 kinase in doublestranded RNA signaling. Nat Struct Mol Biol 11: 1060-7

64. MEYLAN E, BURNS K, HOFMANN K, BLANCHETEAU V, MARTINON F, KELLIHER M, TSCHOPP J 2004 RIP1 is an essential mediator of Toll-like receptor 3- induced NF-kappa B activation. Nat Immunol 5: 503-7

65. JANSSENS S, BEYAERT R 2003 Role of Toll-like receptors in pathogen recognition. Clin Microbiol Rev 16: $637-46$

66. LEBOUDER E, REY-NORES JE, RUSHMERE NK, GRIGOROV M, LAWN SD, AFFOLTER M, GRIFFIN GE, FERRARA P, SCHIFFRIN EJ, MORGAN BP, LABETA MO 2003 Soluble forms of Toll-like receptor (TLR)2 capable of modulating TLR2 signaling are present in human plasma and breast milk. J Immunol 171: 6680- 9

67. IWAMI KI, MATSUGUCHI T, MASUDA A, KIKUCHI T, MUSIKACHAROEN T, YOSHIKAI Y 2000 Cutting edge: naturally occurring soluble form of mouse Toll-like receptor 4 inhibits lipopolysaccharide signaling. J Immunol 165: 6682-6

68. TSUJITA T, ISHII A, TSUKADA H, MATSUMOTO M, CHE FS, SEYA T 2005 Fish soluble Toll-like receptor (TLR)5 amplifies human TLR5 response via physical binding to flagellin. Vaccine 24: 2193-9

69. JANSSENS S, BURNS K, TSCHOPP J, BEYAERT R 2002 Regulation of interleukin- 1- and lipopolysaccharide-induced NF-kappaB activation by alternative splicing of MyD88. Curr Biol 12: 467-71

70. BURNS K, JANSSENS S, BRISSONI B, OLIVOS N, BEYAERT R, TSCHOPP J 2003 Inhibition of interleukin 1 receptor/Toll-like receptor signaling through the alternatively spliced, short form of MyD88 is due to its failure to recruit IRAK-4. J Exp Med 197: 263-8

71. JANSSENS S, BURNS K, VERCAMMEN E, TSCHOPP J, BEYAERT R 2003 MyD88S, a splice variant of MyD88, differentially modulates NFkappaB- and AP-1- dependent gene expression. FEBS Lett 548: 103-7

72. WESCHE H, GAO X, LI X, KIRSCHNING CJ, STARK GR, CAO Z 1999 IRAK-M is a novel member of the Pelle/interleukin-1 receptor-associated kinase (IRAK) family. J Biol Chem 274: 19403-10

73. KOBAYASHI K, HERNANDEZ LD, GALAN JE, JANEWAY CA, JR., MEDZHITOV R, FLAVELL RA 2002 IRAK-M is a negative regulator of Toll-like receptor signaling. Cell 110: 191-202 
74. GINGRAS S, PARGANAS E, DE PAUW A, IHLE JN, MURRAY PJ 2004 Re- examination of the role of suppressor of cytokine signaling 1 (SOCS1) in the regulation of toll-like receptor signaling. J Biol Chem 279: 54702-7

75. YASUKAWA H, OHISHI M, MORI H, MURAKAMI M, CHINEN T, AKI D, HANADA T, TAKEDA K, AKIRA S, HOSHIJIMA M, HIRANO T, CHIEN KR, YOSHIMURA A 2003 IL-6 induces an antiinflammatory response in the absence of SOCS3 in macrophages. Nat Immunol 4: 551-6

76. FUKAO T, TANABE $M$, TERAUCHI Y, OTA $T$, MATSUDA $S$, ASANO T, KADOWAKI T, TAKEUCHI T, KOYASU S 2002 PI3K-mediated negative feedback regulation of IL-12 production in DCs. Nat Immunol 3: 875-81

77. GUHA M, MACKMAN N 2002 The phosphatidylinositol 3-kinase-Akt pathway limits lipopolysaccharide activation of signaling pathways and expression of inflammatory mediators in human monocytic cells. J Biol Chem 277: 32124- 32

78. ARBIBE L, MIRA JP, TEUSCH N, KLINE L, GUHA M, MACKMAN N, GODOWSKI PJ, ULEVITCH RJ, KNAUS UG 2000 Toll-like receptor 2-mediated NFkappa B activation requires a Rac1-dependent pathway. Nat Immunol 1: 533-40

79. STRASSHEIM D, ASEHNOUNE K, PARK JS, KIM JY, HE Q, RICHTER D, KUHN K, MITRA S, ABRAHAM E 2004 Phosphoinositide 3-kinase and Akt occupy central roles in inflammatory responses of Toll-like receptor 2-stimulated neutrophils. J Immunol 172: $5727-33$

80. ZHANG G, GHOSH S 2002 Negative regulation of toll-like receptor-mediated signaling by Tollip. J Biol Chem 277: 7059-65

81. BURNS K, CLATWORTHY J, MARTIN L, MARTINON F, PLUMPTON C, MASCHERA B, LEWIS A, RAY K, TSCHOPP J, VOLPE F 2000 Tollip, a new component of the IL-1RI pathway, links IRAK to the IL-1 receptor. Nat Cell Biol 2: 346-51

82. LI T, HU J, LI L 2004 Characterization of Tollip protein upon Lipopolysaccharide challenge. Mol Immunol 41: 85-92

83. HUGOT JP, CHAMAILLARD M, ZOUALI H, LESAGE S, CEZARD JP, BELAICHE J, ALMER S, TYSK C, O'MORAIN CA, GASSULL M, BINDER V, FINKEL Y, CORTOT A, MODIGLIANI R, LAURENT-PUIG P, GOWER-ROUSSEAU C, MACRY J, COLOMBEL JF, SAHBATOU M, THOMAS G 2001 Association of NOD2 leucine-rich repeat variants with susceptibility to Crohn's disease. Nature 411: 599-603

84. INOHARA N, OGURA Y, FONTALBA A, GUTIERREZ O, PONS F, CRESPO J, FUKASE K, INAMURA S, KUSUMOTO S, HASHIMOTO $\mathrm{M}$, FOSTER SJ, MORAN AP, FERNANDEZ- LUNA JL, NUNEZ G 2003 Host recognition of bacterial muramyl dipeptide mediated through NOD2. Implications for Crohn's disease. J Biol Chem 278: 5509-12

85. GIRARDIN SE, BONECA IG, VIALA J, CHAMAILLARD M, LABIGNE A, THOMAS G, PHILPOTT DJ, SANSONETTI PJ 2003 Nod2 is a general sensor of peptidoglycan through muramyl dipeptide (MDP) detection. J Biol Chem 278: 886972

86. BONEN DK, OGURA Y, NICOLAE DL, INOHARA $\mathrm{N}$, SAAB L, TANABE T, CHEN FF, FOSTER SJ, DUERR RH, BRANT SR, CHO JH, NUNEZ G 2003 Crohn's disease- associated NOD2 variants share a signaling defect in response to lipopolysaccharide and peptidoglycan. Gastroenterology 124: 140-6

87. WATANABE T, KITANI A, MURRAY PJ, STROBER W 2004 NOD2 is a negative regulator of Toll-like receptor 2-mediated $\mathrm{T}$ helper type 1 responses. Nat Immunol 5: 800-8

88. O'NEILL LA, DINARELLO CA 2000 The IL-1 receptor/toll-like receptor superfamily: crucial receptors for inflammation and host defense. Immunol Today 21: 206-9

89. MITA S, TOMINAGA A, HITOSHI Y, SAKAMOTO $\mathrm{K}$, HONJO T, AKAGI M, KIKUCHI Y, YAMAGUCHI N, TAKATSU K 1989 Characterization of high-affinity receptors for interleukin 5 on interleukin 5-dependent cell lines. Proc Natl Acad Sci U S A 86: 2311-5

90. TAGO K, NODA T, HAYAKAWA M, IWAHANA H, YANAGISAWA $\mathrm{K}$, YASHIRO T, TOMINAGA S 2001 Tissue distribution and subcellular localization of a variant form of the human ST2 gene product, ST2V. Biochem Biophys Res Commun 285: 1377-83

91. BERGERS G, REIKERSTORFER A, BRASELMANN S, GRANINGER P, BUSSLINGER M 1994 Alternative promoter usage of the Fos-responsive gene Fit-1 generates mRNA isoforms coding for either secreted or membrane-bound proteins related to the IL-1 receptor. Embo J 13: 1176-88

92. LI H, TAGO K, IO K, KUROIWA K, ARAI T, IWAHANA $\mathrm{H}$, TOMINAGA $\mathrm{S}$, YANAGISAWA K 2000 The cloning and nucleotide sequence of human ST2L cDNA. Genomics 67: 284-90

93. OSHIKAWA K, YANAGISAWA K, TOMINAGA S, SUGIYAMA Y 2002 ST2 protein induced by inflammatory stimuli can modulate acute lung inflammation. Biochem Biophys Res Commun 299: $18-24$

94. TRAJKOVIC V, SWEET MJ, XU D 2004 T1/ST2-an IL-1 receptor-like modulator of immune responses. Cytokine Growth Factor Rev 15: 87-95

95. LECART S, LECOINTE N, SUBRAMANIAM A, ALKAN S, NI D, CHEN R, BOULAY V, PENE J, KUROIWA K, TOMINAGA S, YSSEL H 2002 Activated, but not resting human Th2 cells, in contrast to Th1 and T regulatory cells, produce soluble ST2 and express low levels of ST2L at the cell surface. Eur J Immunol 32: 2979-87

96. SWEET MJ, LEUNG BP, KANG D, SOGAARD M, SCHULZ K, TRAJKOVIC V, CAMPBELL CC, XU D, LIEW FY 2001 A novel pathway regulating lipopolysaccharide- induced shock by ST2/T1 via inhibition of Toll-like receptor 4 expression. J Immunol 166: 6633-9

97. XU D, CHAN WL, LEUNG BP, HUANG $F$, WHEELER R, PIEDRAFITA D, ROBINSON JH, LIEW FY 1998 Selective expression of a stable cell surface molecule on type 2 but not type 1 helper $\mathrm{T}$ cells. J Exp Med 187: 787-94

98. COYLE AJ, LLOYD C, TIAN J, NGUYEN T, ERIKKSON C, WANG L, OTTOSON P, PERSSON P, DELANEY T, LEHAR S, LIN S, POISSON L, MEISEL C, KAMRADT T, BJERKE T, LEVINSON D, GUTIERREZ-RAMOS JC 1999 Crucial role of the interleukin 1 receptor family member $\mathrm{T} 1 / \mathrm{ST} 2$ in $\mathrm{T}$ helper cell type 2- mediated lung mucosal immune responses. J Exp Med 190: 895-902

99. BRINT EK, XU D, LIU H, DUNNE A, MCKENZIE AN, O'NEILL LA, LIEW FY 2004 ST2 is an inhibitor of interleukin 1 receptor and Toll-like receptor 4 signaling and maintains endotoxin tolerance. Nat Immunol 5: 373-9 
100. SCHMITZ J, OWYANG A, OLDHAM E, SONG Y, MURPHY E, MCCLANAHAN TK, ZURAWSKI G, MOSHREFI M, QIN J, LI X, GORMAN DM, BAZAN JF, KASTELEIN RA 2005 IL-33, an interleukin-1-like cytokine that signals via the IL-1 receptor- related protein ST2 and induces T helper type 2-associated cytokines. Immunity 23: 479-90

101. KUMAR S, TZIMAS MN, GRISWOLD DE, YOUNG PR 1997 Expression of ST2, an interleukin-1 receptor homologue, is induced by proinflammatory stimuli. Biochem Biophys Res Commun 235: 474-8

102. WALD D, QIN J, ZHAO Z, QIAN Y, NARAMURA M, TIAN L, TOWNE J, SIMS JE, STARK GR, LI X 2003 SIGIRR, a negative regulator of Toll-like receptor- interleukin 1 receptor signaling. Nat Immunol 4: 920-7

103. QIN J, QIAN Y, YAO J, GRACE C, LI X 2005 SIGIRR inhibits interleukin-1 receptor- and toll-like receptor 4-mediated signaling through different mechanisms. J Biol Chem 280: 25233-41

104. THOMASSEN E, RENSHAW BR, SIMS JE 1999 Identification and characterization of SIGIRR, a molecule representing a novel subtype of the IL-1R superfamily. Cytokine 11: 389-99

105. SCHWARTZ DA, COOK DN 2005 Polymorphisms of the Toll-like receptors and human disease. Clin Infect Dis 41 Suppl 7: S403-7

106. FETEROWSKI C, EMMANUILIDIS K, MIETHKE T, GERAUER K, RUMP M, ULM K, HOLZMANN B, WEIGHARDT H 2003 Effects of functional Toll-like receptor-4 mutations on the immune response to human and experimental sepsis. Immunology 109: 426-31

107. BRAUN-FAHRLANDER C, RIEDLER J, HERZ U, EDER W, WASER M, GRIZE L, MAISCH S, CARR D, GERLACH F, BUFE A, LAUENER RP, SCHIERL R, RENZ H, NOWAK D, VON MUTIUS E 2002 Environmental exposure to endotoxin and its relation to asthma in school-age children. N Engl J Med 347: 869-77

108. GEHRING U, BISCHOF W, FAHLBUSCH B, WICHMANN HE, HEINRICH J 2002 House dust endotoxin and allergic sensitization in children. Am J Respir Crit Care Med 166: 939-44

109. RADSTAKE TR, FRANKE B, HANSSEN S, NETEA MG, WELSING P, BARRERA P, JOOSTEN LA, VAN RIEL PL, VAN DEN BERG WB 2004 The Tolllike receptor 4 Asp299Gly functional variant is associated with decreased rheumatoid arthritis disease susceptibility but does not influence disease severity and/or outcome. Arthritis Rheum 50: 999-1001

110. GALON J, FRANCHIMONT D, HIROI N, FREY G, BOETTNER A, EHRHART-BORNSTEIN M, O'SHEA JJ, CHROUSOS GP, BORNSTEIN SR 2002 Gene profiling reveals unknown enhancing and suppressive actions of glucocorticoids on immune cells. Faseb J 16: 61-71

111. LORENZ E, MIRA JP, CORNISH KL, ARBOUR NC, SCHWARTZ DA 2000 A novel polymorphism in the toll-like receptor 2 gene and its potential association with staphylococcal infection. Infect Immun 68: 6398401

112. OGUS AC, YOLDAS B, OZDEMIR T, UGUZ A, OLCEN S, KESER I, COSKUN M, CILLI A, YEGIN O 2004 The Arg753GLn polymorphism of the human toll-like receptor 2 gene in tuberculosis disease. Eur Respir J 23: 219-23

113. LAWTON JA, GHOSH P 2003 Novel therapeutic strategies based on toll-like receptor signaling. Curr Opin Chem Biol 7: 446-51
114. BRUGNOLO F, SAMPOGNARO S, LIOTTA $F$, COSMI L, ANNUNZIATO F, MANUELLI C, CAMPI P, MAGGI E, ROMAGNANI S, PARRONCHI P 2003 The novel synthetic immune response modifier R-848 (Resiquimod) shifts human allergen- specific CD4+ TH2 lymphocytes into IFN-gamma-producing cells. J Allergy Clin Immunol 111: 380-8

115. KNUEFERMANN P, NEMOTO S, BAUMGARTEN $\mathrm{G}$, MISRA A, SIVASUBRAMANIAN N, CARABELLO BA, VALLEJO JG 2002 Cardiac inflammation and innate immunity in septic shock: is there a role for toll-like receptors? Chest 121: 1329-36

116. KAPADIA S, LEE J, TORRE-AMIONE G, BIRDSALL HH, MA TS, MANN DL 1995 Tumor necrosis factor-alpha gene and protein expression in adult feline myocardium after endotoxin administration. J Clin Invest 96: 1042-52

117. BAUMGARTEN G, KNUEFERMANN P, NOZAKI $\mathrm{N}$, SIVASUBRAMANIAN N, MANN DL, VALLEJO JG 2001 In vivo expression of proinflammatory mediators in the adult heart after endotoxin administration: the role of toll-like receptor-4. J Infect Dis 183: 1617-24

118. SCHUSTER JM, NELSON PS 2000 Toll receptors: an expanding role in our understanding of human disease. J Leukoc Biol 67: 767-73

119. KATZE MG, HE Y, GALE M, JR 2002 Viruses and interferon: a fight for supremacy. Nat Rev Immunol 2: $675-87$

120. VAN HEEL DA, GHOSH S, BUTLER M, HUNT KA, LUNDBERG AM, AHMAD T, MCGOVERN DP, ONNIE C, NEGORO K, GOLDTHORPE S, FOXWELL BM, MATHEW CG, FORBES A, JEWELL DP, PLAYFORD RJ 2005 Muramyl dipeptide and toll- like receptor sensitivity in NOD2associated Crohn's disease. Lancet 365: 1794-6

121. MCINTURFF JE, MODLIN RL, KIM J 2005 The role of toll-like receptors in the pathogenesis and treatment of dermatological disease. J Invest Dermatol 125: 1-8

122. HECKELSMILLER K, BECK S, RALL K, SIPOS B, SCHLAMP A, TUMA E, ROTHENFUSSER S, ENDRES S, HARTMANN G 2002 Combined dendritic cell- and CpG oligonucleotide-based immune therapy cures large murine tumors that resist chemotherapy. Eur J Immunol 32: 3235-45

123. EGETER O, MOCIKAT R, GHORESCHI K, DIECKMANN A, ROCKEN M 2000 Eradication of disseminated lymphomas with CpG-DNA activated T helper type 1 cells from nontransgenic mice. Cancer Res 60: 1515-20

124. KRIEG AM 2002 A role for Toll in autoimmunity. Nat Immunol 3: 423-4

125. LEADBETTER EA, RIFKIN IR, HOHLBAUM AM, BEAUDETTE BC, SHLOMCHIK MJ, MARSHAKROTHSTEIN A 2002 Chromatin-IgG complexes activate B cells by dual engagement of IgM and Tolllike receptors. Nature 416: 603-7

126. PISETSKY DS, WENK KS, REICH CF, 3rd 2001 The role of cpg sequences in the induction of anti-DNA antibodies. Clin Immunol 100: 157-63

127. LEADBETTER EA, RIFKIN IR, MARSHAKROTHSTEIN A 2003 Toll-like receptors and activation of autoreactive B cells. Curr Dir Autoimmun 6: 105-22

128. ANDERS HJ 2005 A Toll for lupus. Lupus 14: 417-22

129. BAKER BS, OVIGNE JM, POWLES AV, CORCORAN S, FRY L 2003 Normal keratinocytes express Toll-like receptors (TLRs) 1, 2 and 5: modulation of TLR expression in chronic plaque psoriasis. Br J Dermatol 148: 670-9 
130. PIVARCSI A, BODAI L, RETHI B, KENDERESSYSZABO A, KORECK A, SZELL M, BEER Z, BATACSORGOO Z, MAGOCSI M, RAJNAVOLGYI E, DOBOZY A, KEMENY L 2003 Expression and function of Toll-like receptors 2 and 4 in human keratinocytes. Int Immunol 15: 721-30

131. CURRY JL, QIN JZ, BONISH B, CARRICK R,
BACON P, PANELLA J, ROBINSON J, NICKOLOFF BJ 2003 Innate immune-related receptors in normal and psoriatic skin. Arch Pathol Lab Med 127: 178-86

132. MCINTURFF JE, KIM J 2005 The role of toll-like receptors in the pathophysiology of acne. Semin Cutan Med Surg 24: 73-8 